\title{
Impact of Fashion Entrepreneurship Programme on Entrepreneurial Interests, Intention and Competencies
}

\author{
Rahimah Jamaluddin ${ }^{1^{*}}$, Mass Hareza Ali $^{2}$, Suhaida Abdul Kadir ${ }^{3}$, Arasinah \\ Kamis $^{4}$
}

${ }^{1}$ Faculty of Educational Studies, Universiti Putra Malaysia, Serdang, 43400, MALAYSIA

${ }^{2}$ Centre of Entrepreneurial Development and Graduate Marketability, Universiti Putra Malaysia, Serdang, 43400, MALAYSIA

${ }^{3}$ Faculty of Educational Studies, Universiti Putra Malaysia, Serdang, 43400, MALAYSIA

${ }^{4}$ Faculty of Technical \& Vocational, Sultan Idris Education University, Tanjung Malim, 35900, MALAYSIA

DOI: https://doi.org/10.30880/jtet.2019.11.01.015

Received $15^{\text {th }}$ August 2018; Accepted $14^{\text {th }}$ November 2018; Available online $31^{\text {st }}$ March 2019

\begin{abstract}
Entrepreneurship education has traditionally focused on formal education, but many initiatives have been taken parallel with the $21^{\text {st }}$ century teaching and learning strategies to engage student experience through learning by doing. The purpose of this study was to examine the impact of entrepreneurship education on students' entrepreneurship interest, intentions and competencies by implementing fashion entrepreneurship program. This study was held at Universiti Putra Malaysia for a period of five months. Samples were selected among undergraduate students who enrolled in Entrepreneurship Courses in First Semester 2016/2017. Screening process comprises interviews and basic sewing test were conducted to select 40 students as the respondents of the program. This program emphasized mentor-mentees system which involved 10 fashion entrepreneurs from the community. Respondents were exposed to entrepreneurship seminars, business and skills trainings, e-marketing workshops, sewing classes as well as evaluation sessions. Qualitative data were gathered through questionnaires adapted from Mc Clellandand Mc Ber \& Co (1985) as well as questionnaires by Hisyamudin Hassan (2007). Meanwhile qualitative data were collected through continuous observations and the output of the fashion products. The findings indicated that there is a significant positive correlation between entrepreneurship interests with entrepreneurship intentions. Although the findings showed no significant relationship between fashion entrepreneurship program with entrepreneurship intentions and competencies, respondents' perceptions towards their interest, intentions and competencies at the end of the program are high. Due to time constraints, it was suggested that future entrepreneurship program should be scheduled more structured and in a timely manner to ensure that student can gain benefit throughout the program and the objective of the program can be achieved.
\end{abstract}

Keywords: Fashion Entrepreneurship, Learning by Doing, Entrepreneurship Education, Entrepreneurship Intentions, Entrepreneurship Outcomes

\section{Introduction}

Malaysia has set the goal of becoming a high-income nation by 2020 . To achieve this goal, the country's economic growth engine has been devoted to entrepreneurship. According to the report of Entrepreneurship Strategic Plan 2013- 
2015 for Higher Learning Institution, it was found that the percentage of students who were exposed to entrepreneurship education increased from 16.7\% in 2011 to 34.6\% in the year 2013 (Economic Planning Unit, 2016). Therefore, Entrepreneurship Action Plan for Higher Education Institutions (HEIs) 2016 to 2020 was launched to ensure the continuation of previous policies and plans. It still retains the ultimate goal of producing more job creators rather than job seekers among university graduates. According to statistic of labour force in Malaysia 2018, the national percentage of unemployed is 3.4. Even though the percentage is small but the main contributor for the percentage is among university students. Unemployment rate among youth with tertiary education are $23 \%$ compare to youth without tertiary education only $9.8 \%$. It was reported that one out of four university graduates could not get a job in six months and only $2 \%$ of young graduates start their own business. The unemployment problem leads to wastage of manpower because the skills and knowledge possessed by the graduates cannot be used to contribute to national development. Only a fraction of graduates tends to become entrepreneurs after graduation which indicates a lack of effectiveness of entrepreneurship education in universities towards producing more young entrepreneurs.

Most of the students do not aim to run a business even on a small scale because they are not exposed to business opportunities that may be available. Apart from lack of ideas, they are also worried about the inadequacy of skills, lack of experience, and lack of capital to start a business. In fact, there are students who think that they can only venture into business after their graduation and thus, they focus on their studies without having any second thoughts of starting a business during their undergraduate period. Students need support to equip themselves with various skills in developing the characteristics of an entrepreneur as they do not have the confidence in their ability to become an entrepreneur. Most of them do not want to take risks venturing in business and have a fixed mind-set that a business requires substantial capital. A study by Norashidah, Norasmah and Hariyaty (2009) have proved that the absence of courage to take risks, lack of believe in one's ability to make decisions and lack of self-confidence are obstacles faced by the students of National University of Malaysia to conduct small business on a part-time basis.

One way to address this incrementally, HEIs should provide the needed stimulus for students to apply the knowledge and practice entrepreneurial by providing a place for them to start a business. Students should be equipped with skills beyond their field of study besides engaging them with informal entrepreneurship programs. In addition to producing more entrepreneurs among students as a catalyst for the transformation of the economy and to achieve zero unemployment, characteristics of entrepreneurship need to be cultivated in them. Therefore, they are not too dependent on the availability of jobs out there that are becoming increasingly scarce.

Technological developments and the use of the Internet have boosted the fashion industry in Malaysia. Exposure of international fashion through the mass media has contributed to the development of the fashion industry that involves the use of fabrics and textiles. According to the report Outlook for the retail and consumer products sector in Asia 2015-2016, the growth of fashion and clothing in Asia will continue to rise to over 9.5\% in 2018 (PwC, 2015). Parallel to this, it has become the latest trend where most of the university students have started their own business around the campus either online or offline. Social network medium that students normally use are Facebook and Instagram. Products that reach the highest demand among female students are products that are particularly related to fashion like clothing and accessories. Variety of scarves, maxi dresses, robes and others has raised students' interest to enter fashion industry even though they do not have the knowledge and skills in the field.

Currently, entrepreneurship has become a compulsory subject in tertiary level. The exposure of this subject will increase students' knowledge and interest in becoming an entrepreneur once they have completed their studies. Entrepreneurship education have been identified as determinants on entrepreneurship intentions and outcomes (Hussain \& Norashidah, 2015; Matlay, 2008; Khuong \& An, 2016; Døgan, 2015; Tshikovhi \& Shambare, 2015; Chang \& Rieple, 2013). In the context of Malaysia, few researches have been carried out to study the impact of entrepreneurship education, particularly related with hands-on and practical trainings in the areas of fashion. Zhang, Duyster and Cloodt, (2013) identified that limited studies have been conducted to analyze the impact of different components taught on the entrepreneurial education and intentions during entrepreneurial education courses and trainings.

In response to extremely high demand in the field of fashion industry in Malaysia, as well as to cultivate entrepreneurship interest among the female students in this field, this program is provided as a platform for them to gain experience by learning through doing. By participating in this program, students will not only have the opportunity to have their own business and the products, but they will be better-prepared in the fashion business as well as the knowledge and confidence to step up to a more challenging world of business. Thus, this paper focused on how universities can educate successful entrepreneurs by looking at the activities that are more specifically aimed at training graduates to become future fashion entrepreneurs. The purpose of this paper was to investigate the impact of entrepreneurship education by implementing fashion entrepreneurship program on students' entrepreneurship interest, intentions and competencies.

\subsection{Overview of Fashion Entrepreneurship Programs}

In this study, we have set up a program which aimed to nurture graduates to become a successful fashion entrepreneur. This program is named as "Siswa@Fesyen". The focus of this program is in line with Entrepreneurship Development Policy of Higher Education Institute, which aims to create a model of high quality that has the characteristics and qualities of an entrepreneur and produce more entrepreneurs among graduates who will be a catalyst in the 
transformation towards a developed nation with high income. This program was conducted in collaboration with the Faculty of Educational Studies, Universiti of Putra Malaysia. The program was operated entirely by the Unit of Home Economics Education under the Department of Science and Technical Education, Faculty of Education. This program involved 40 respondents consisted of bachelor students from various field of studies studying in UPM. The duration of this program was for five months which was from October 2016 until February 2017.

The respondents of this program were given an intensive training to enable them to master the relevant skills and knowledge to become fashion entrepreneurs. This program was designed uniquely by considering the need to allow the respondents to experience running a business through learning by doing. Another consideration made in this program was by having the mentor-mentee system. 10 fashion entrepreneurs were invited to contribute to the success of this program. Mentors were nearby community members who participated in this program voluntarily. Mentor-mentee system was applied in this program with the intention of providing continuous support to the respondents with business knowledge, skills and current trends related to fashion industry. Indirectly, it was expected that through this program, the 'entrepreneur spirit' can be cultivated among the respondents. In this program, the respondents were taught on business canvas models, on-line marketing as well as short courses in making dresses. Respondents were then divided into 10 groups by random with one mentor to supervise for each group. This program consists of four phases as shown in Table 1.

\begin{tabular}{ll} 
& Table 1 - Phases of "Siswa@Fesyen" \\
\hline Phase & Activities \\
\hline Phase 1 & Business Model Generation \\
& Activity 1: Entrepreneurship Seminar \\
Phase 2 & Practical Training \\
& Activity 1: Business and Skills Training \\
& Activity 2: E-Marketing Workshop \\
Phase 3 & Practical Training \\
& Activity 1: Drafting pattern \\
& Activity 2: Sewing process \\
Phase 4 & Evaluation Session and Closing Ceremony \\
& Activity 1: Evaluation Session \\
& Activity 2: Fashion Show \\
\hline
\end{tabular}

\section{Entrepreneurship Related Works}

This project utilized the theoretical concepts of Entrepreneurship Intentions Model introduced by Ajzen (1991). Ajzen identified three elements responsible for encouraging entrepreneurial behavior which are entrepreneurship knowledge, personal attitudes, and entrepreneurship intentions. The model pre-supposes that the interaction of these three variables ultimately define individuals' proclivity towards entrepreneurship. Referring to the Model of Entrepreneurship Learning (Hynes, 1996) and Kolb Learning Model (1984), the formation of skills and behavior are influenced by how the learning process occurs. In consistent with that, Gibb (2011) clarified that the pedagogy used for entrepreneurship education should be carried out in various learning environments (Syed Zamberi, 2012; Ruskovaara \& Pihkala, 2012) which involves an active role of students in the learning process (Cedefop, 2006).

\subsection{Entrepreneurship Education}

Jones and English (2004) defined entrepreneurship education as the process of providing individuals with the ability to recognize commercial opportunities and the insight, self-esteem, knowledge and skills to act on them. Entrepreneurship education may promote an awareness of self-employment as a career option; it is suggested that this awareness motivates young people to equip themselves with the skills, knowledge and experience required for effective business ownership (Norasmah, 2012). Hence it can be concluded that, teaching of entrepreneurship can provide students with an understanding of business - its purposes, its structure, its interrelationship with other segments of the economy and society (Klapper, 2004).

In order to encourage young generations to becomes entrepreneurs, it was suggested that entrepreneurship education be cultivated early in an individual's life (Kourilsky \& Walstad, 1998). Waldmann (1997) clarified that entrepreneurship education at an early stage will give impact on students' intentions to consider starting a business sometime after they complete their studies. It is important to make sure the entrepreneurship education given at the early stage incorporates two main components, theoretical (understanding steps in the start-up process) and practical (know-how). Similarly, entrepreneurship learning also comprises theoretical (triggered by external sources such as people or academic literature) and practical (typically triggered by group-based, practical hands-on exercises) components (Nabi, Walmsley, Linan, Akhtar \& Neame (2018). These two types of inspiration can be very powerful and will change hearts and/or minds and yet influence students' higher entrepreneurial intentions. Knowing the importance of entrepreneurship, Malaysian education system emphasizes the development of entrepreneurship, by 
considering entrepreneurship into curricula starting from the primary until tertiary level. Development of entrepreneurship in Malaysia has been growing rapidly since the offering of entrepreneurship education in the mid1990s (Mohd Khairuddin \& Syed Azizi, 2002; Armanurah, Abdul Razak \& Syahrina, 2005). This action initiated by the Ministry of Education Malaysia aimed to achieve the Eleventh Malaysian Plan (2016-2020) in producing job creators rather than job seekers by the year 2020.

Entrepreneurship education can be taught whether in informal or formal education. Some researchers suggested that formal entrepreneurship education is capable to produce entrepreneurs among graduates (Hussain \& Norashidah, 2015; Matlay, 2008; Khuong \& An, 2016; Doğa*, 2015; Tshikovhi \& Shambare, 2015; Chang \& Rieple, 2013). Meanwhile Zainal Abidin, Golnaz, Amin and Ezhar (2011) found that informal entrepreneurship education seems to be more effective in influencing graduates to participate in entrepreneurship activities. In addition to that, Noorkartina, HockEam, Norhafezah and Jan-Jan (2015) asserted that there were no differences in having entrepreneurship education either formally or informally because both significantly influence students' entrepreneurship intention. Therefore, it is suggested that both formal and informal entrepreneurship education should be implemented into the curriculum in order to cultivate entrepreneurial intentions to the students. In terms of pedagogy, it is suggested that entrepreneurship education requires a shift in pedagogy because there is a need for universities to improve teaching strategies if we wish to increase students' intentions to choose entrepreneurship as a career choice (Syed Zamberi, 2012; Zaidatol Akmaliah, 2009).

Formal entrepreneurship refers to organized and structured learning in an educational institution. According to Malaysian Education Blueprint 2013-2025 (KPM, 2012) entrepreneurship education was designed with the aims of enhancing and developing entrepreneurship awareness among the students and also to influence graduates' entrepreneurial mindset (Pittaway and Edwards, 2012). Delivering entrepreneurship education can be done in various ways. Previous studies have confirmed that learning by doing which involves self-experiences, acquiring independent learning skills and practices (Noorkartina et al., 2015) are an excellent strategy to enhance entrepreneurial intentions and competencies (Bird, 1998; Kolb, 1984; Lackeus, 2015). Among the recommended activities are as in live project (Chang \& Rieple, 2013), enterprise or entrepreneurial project (Hussain \& Norashidah, 2015; Tshikovhi \& Shambare, 2015; Peterman, 2003) and action-based (Rasmussen \& Sorheim, 2006). As such Linan, Rodriguez-Cohard and RuedaCantuche (2011) particularly explains that exposure to the business environment makes students more confident about their own abilities of becoming entrepreneurs.

\subsection{Entrepreneurship Education}

Entrepreneurship outcomes can be measured from two perspectives; entrepreneurship competencies and entrepreneurship intentions. Competency is a broad concept that refers to a person's ability to use knowledge and other capabilities needed to get a better performance in the work done (Kaur \& Bains, 2013). According to a study conducted by Mc Clelland and Mc Ber \& Co. (1985) involving successful entrepreneurs in Malawi, India and Ecuador, they found out that there were thirteen characteristics of personal entrepreneurial competencies which are initiatives, see and act on opportunities, persistence, information seeking, concern for high quality of work, committed to work contract, efficiency orientation, systematic planning, problem solving, self-confident, assertiveness, persuasion and use of influential strategies. All of these features are necessary for the entrepreneurs to be more efficient and competitive.

Bygrave (1989) defined entrepreneurship intention as the growing conscious state of mind that a desire to start a new enterprise or create new core value in an existing organization. With simpler words, entrepreneurship intention means an individual wants to start some entrepreneurship activities (Souitaris, 2007). Previous study indicated that the person who have a greater entrepreneurial characteristic tend to have higher intention to start their own business. Entrepreneurial intention is influenced by several characteristics such as age, gender, skills, interest, personalities, education, knowledge and prior experience (Noorkartina et al., 2015; Krueger \& Carsrud, 1993; Matlay, 2008; Norhatta et al., 2015; Tshikovhi \& Shambare, 2015, Nabi et al., 2018). These characteristics have been proved as influencing factors of entrepreneurship intention (Fitzsimmons \& Douglas, 2011) and entrepreneurship competencies (Krueger \& Carsrud, 1993). In this study, respondents were selected from those who have already attended entrepreneurship courses and have basic skills in sewing. Some of the respondents had been involved in small business. As the respondents have met some of the features mentioned, it is important to study the entrepreneurial intention among the respondents after they joined the program.

It was found that entrepreneurship education can significantly change the entrepreneurship intentions and outcomes of the respondents. Matlay (2008) in his study found that entrepreneurship education has a positive impact upon entrepreneurial outcomes related to the career aspirations. Out of 64 graduates in the research sample, none of the graduates became unemployed or acquired employee status over the ten years period. He also found that there was a relatively speedy progression from self-employed status to micro-and small business ownership. In line with that, Hussain and Norashidah (2015) carried out their research on 499 final year undergraduate and graduate students of business studies in Pakistan. Result of their study confirmed that entrepreneurship education plays an important role in enhancing the entrepreneurial intentions. This finding supports the finding of Doğan ${ }^{*}$ (2015) who reported a significant positive relation between entrepreneurship education and entrepreneurial intention. 
Other than that, according to Rasmussen and Sørheim (2006) the success of an entrepreneurship program requires support of external resources and financial resources. External resources contribute with relevance and up-to-date reallife experience. These external people provide a network and access to other networks, thus helping the respondents to build their own networks and relate to external contacts. Involvement of role-models through the mentoring system can contribute significantly to move the project or start-up company forward. The second important resource is financial support from public or private funding. This funding is indispensable to enable a program to run smoothly in order to achieve the goals. In line with this, Chang and Rieple (2013) indicated that the development of entrepreneurial skills can be improved by providing a learning environment in which students interact with real business people in live projects. They also indicated that entrepreneurship education programs may be improved by scheduling skills training in a more structured and timely manner. Therefore, it is important to get the involvement of business community or entrepreneurs in order to facilitate the development and success of entrepreneurship programs among the students.

\subsection{Research Methodology}

This mix method study was conducted at the Universiti of Putra Malaysia. Purposive sampling technique was applying to select 40 first year undergraduate student who enroll in Entrepreneurship course in first semester 2016/2017. Screening process comprises interviews and basic sewing skills tests were carried out at the beginning of the study. Selected samples were then needed to attend and commit to the training program provided by the organizer. Three questionnaires were used; (1) personal entrepreneurship competencies questionnaires adapted from Mc Clelland and Mc Ber \& Co (1985), (2) entrepreneurship intentions and interest questionnaires adapted from Hisyamudin Hassan (2007), (3) implementation of fashion entrepreneurship program developed by researcher based on the activities carried out.

The entrepreneurship competencies instrument was divided into 13 constructs; initiative, see and act on opportunities, persistence, information seeking, concern for high quality of work, committed to work contract, efficiency orientation, systematic planning, problem solving, self-confident, assertiveness, persuasion and use of influential strategies. 5-point Likert scale from (1) strongly disagree until (5) strongly agree were used. Meanwhile for entrepreneurship intentions, the scores were range from (1) not capable until (5) very capable were used. Students' level of entrepreneurship outcomes was measure using mean score with low (mean of 1.00 to 2.33), moderate (mean of 2.34 to 3.66 ) and high (mean of 3.67 to 5.00 ).

The instrument showed high reliability and acceptable with alpha cronbach value of $0.76-0.90$ as shown in the Table 2 for all constructs (Nunally, 1993). The data was then analysed using the IBM SPSS, descriptive and inferential statistic were used to analyse all the research questions.

Table 2 - Reliability of All Constructs

\begin{tabular}{lcc}
\hline Construct & $\begin{array}{c}\text { Number of } \\
\text { Items }\end{array}$ & $\begin{array}{c}\text { Cronbach's } \\
\text { Alpha }\end{array}$ \\
\hline Entrepreneurship intentions & 5 & .79 \\
Entrepreneurship competencies & 50 & .87 \\
Entrepreneurship interest & 11 & .76 \\
Implementation of Fashion Entrepreneurship Program & 25 & .90 \\
\hline
\end{tabular}

\subsection{Research Finding}

\subsection{Quantitative Findings}

The sample comprised of 40 undergraduate students from various bachelor programs. The distribution of respondents by gender is illustrated in Table 3. Findings shows that $36(90 \%)$ of the respondent were female and only $4(10 \%)$ were male.

Table 3 - Gender of Respondents

\begin{tabular}{lcc}
\hline & Frequency (n) & Percentage \% \\
\hline Male & 4 & 10 \\
Female & 36 & 90 \\
\hline
\end{tabular}

As shown in Figure 1, 32 (80\%) respondents have attended entrepreneurship education and 30 (75\%) respondents have experienced related to entrepreneurship training previously. Besides that, 21 (52.5\%) of respondents have experience in running a fashion-related business and the rest 19 (47.5\%) respondents had no experience in running a fashion-related business before. 


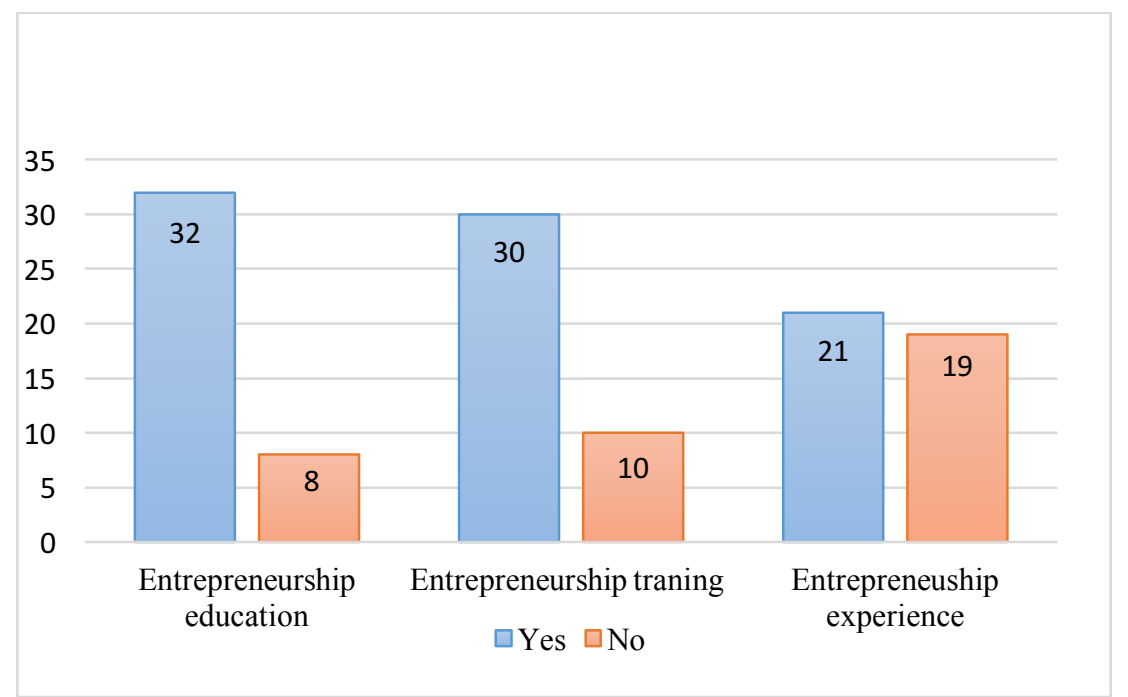

Fig. 1 - Distribution of entrepreneurship education, entrepreneurship training and entrepreneurial experience among respondents

Table 4 illustrates the mean and standard deviation of entrepreneurship intentions, entrepreneurship competencies, fashion's entrepreneurship program and entrepreneurship interest. Based on the findings, the entire constructs measured in this study indicated mean value above 3.0. It means that the respondents have high perceptions of their entrepreneurship intentions (mean=3.62 and $\mathrm{std}=0.59)$, entrepreneurship competencies (mean=3.82 and $\mathrm{std}=0.27$ ), and entrepreneurship interest (mean $=3.35$ and $s t d=0.34$ ) throughout the program. In addition, respondents evaluate the fashion entrepreneurship program as good with the mean value of 4.01 and standard deviation of 0.45 .

Table 4 - Mean and Standard Deviation of Entrepreneurship Outcomes

\begin{tabular}{lcc}
\hline Construct & Mean & Std. Deviation \\
\hline Entrepreneurship intentions & 3.62 & 0.59 \\
Entrepreneurship competencies & 3.82 & 0.27 \\
Fashion Entrepreneurship Program & 4.01 & 0.45 \\
Entrepreneurship interest & 3.35 & 0.34 \\
\hline
\end{tabular}

Findings also shows that (Table 5) the mean value for all 13 constructs of entrepreneurship competencies are high and ranges from 3.47 to 4.12 . Therefore, it can be concluded that respondents are able to dominate all the construct of competencies after they finish the program.

Table 5 - Mean and Standard Deviation of Entrepreneurship Competencies Constructs

\begin{tabular}{|c|c|c|}
\hline Entrepreneurship competencies & Mean & Std. Deviation \\
\hline \multicolumn{3}{|l|}{ Construct: } \\
\hline Initiative & 3.65 & 0.37 \\
\hline See and act on opportunities & 3.94 & 0.42 \\
\hline Persistence & 3.88 & 0.41 \\
\hline Information seeking & 4.12 & 0.41 \\
\hline Concern for high quality of work & 4.03 & 0.42 \\
\hline Committed to work contract & 4.09 & 0.33 \\
\hline Efficiency orientation & 4.10 & 0.39 \\
\hline Systematic planning & 4.04 & 0.40 \\
\hline Problem solving & 3.79 & 0.36 \\
\hline 10) Self-confident & 3.60 & 0.59 \\
\hline 11) Assertiveness & 3.62 & 0.46 \\
\hline 12) Persuasion & 3.47 & 0.47 \\
\hline 13) Use of influential strategies & 3.76 & 0.49 \\
\hline
\end{tabular}


According to Table 6, findings showed that there is a significant relationship between entrepreneurship interests with entrepreneurship intentions $(\mathrm{r}=0.374, \mathrm{p}<0.05)$. However, there is no significant relationship between fashion entrepreneurship with entrepreneurship intentions $(r=0.269, \mathrm{p}>0.05)$.

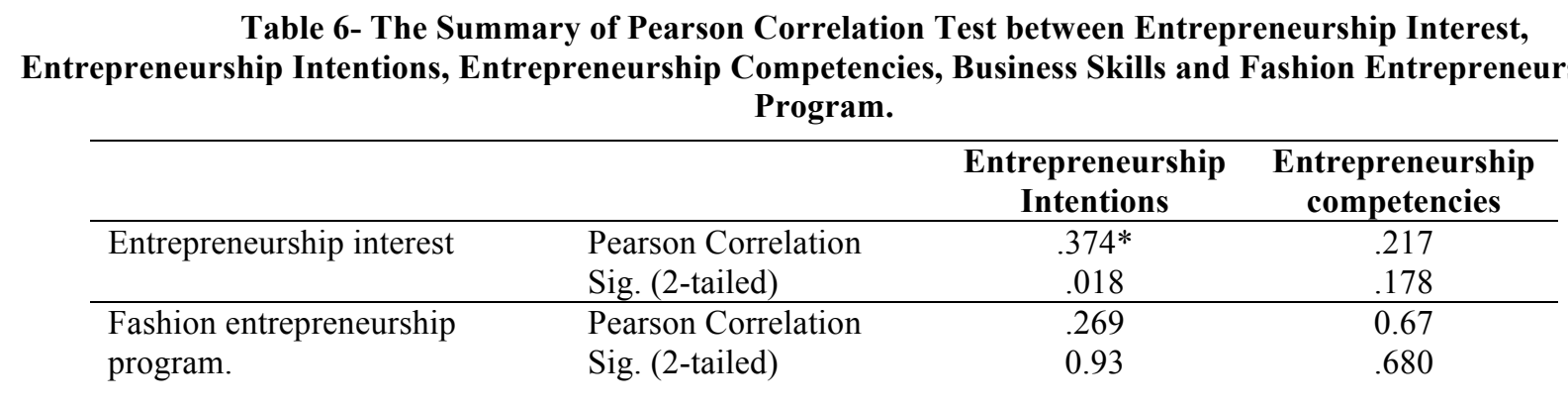

** Correlation is significant at 0.01 level (2-tailed)

* Correlation is significant at 0.05 level (2-tailed)

\subsection{Qualitative Findings}

Continued observations were done to monitor respondent engagement and participation. Respondents demonstrate high interest and commitment at the beginning of the program. All of the respondent $(100 \%)$ attended the Entrepreneurship Seminar. They also fulfil the task in phase 2 which require them to attended Business and Skills Training as well as EMarketing Workshop. Respondents were asked to create their group theme, logo, and their e-marketing platform on Instagram or Facebook. They did it very well at this phase and enjoy the training. Phase 3 was the challenge for them, whereby they need to design clothes based on the theme given by the organizer. Each group need to come out with ideas and design a Muslim Women Night Dress. Due to limited sewing skills, they were needed to attend sewing classes and come to the sewing lab every Friday afternoon. The main problem here were some of them had classes in the afternoon whilst some had other assignments and commitments to do. They didn't have enough time to be in groups and meeting with their mentors. The participations of the respondent at this phase dropped to 50\%. Their main constraints were to find suitable time where they can gather together and do their sewing task. However, there are mentors who are very concerned and took the initiative by picking them up to their own boutique on Saturday and Sunday. To overcome this problem, more time were given to them to complete the sewing task until the end of semester after they have finished with their final exam. Last phase was very fun and meaningful, the participations of the respondent increased to $100 \%$ and their commitment were very excellent. Respondents were then required to do three-minute pitching in front of a few referees as well as a fashion show at the closing ceremony. Overall, researcher found that this program was a good platform for the beginner, since it can cultivate 'entrepreneur spirit' as well as foster their interest, intentions and competencies to become a fashion entrepreneurs in future. Although duration of the program was very short and respondents had limited sewing skills, they managed to produce creative and attractive dress.

\subsection{Discussions}

This study examines entrepreneurship interest, intentions and competencies of undergraduate students who attended the fashion entrepreneurship program. It was found that the respondents' perceptions towards their interest, intentions and competencies are high. These findings indicate that the fashion entrepreneurship program has successfully cultivated entrepreneurship interest, intentions and competencies among the respondents. This finding is consistent with Hussain and Norashidah (2015); Matlay (2008); Khuong and An (2016); Doğa* (2015); Tshikovhi and Shambare (2015) and Chang and Rieple (2013) who reported that entrepreneurship education contributes to entrepreneurship intentions. These findings also supported Kourilsky and Walstad (1998) who suggested that entrepreneurship education needs to be taught at early stages because it not only cultivates students' entrepreneurship intentions, but it also can influence students to choose entrepreneurship as their career upon the completion of their studies (Matlay, 2008; Waldmann, 1997).

In addition to that, analysis of Pearson correlation showed that there is a significant relationship between entrepreneurship interest and entrepreneurship intentions. This finding proved that entrepreneurial intention is influenced by an individual's characteristics. In this study, the students' interest on fashion entrepreneurship, prior experience in implementing fashion-related business and knowledge that they gained from previous courses and training has a great influence towards their intentions. This finding is in line with the previous research done by Noorkartina et al., (2015); Krueger and Carsrud (1993); Matlay (2008); Norhatta et al., (2015) and Tshikovhi and Shambare (2015). 
Nevertheless, it was found that there is no significant relationship between fashion entrepreneurship program with entrepreneurship intentions and entrepreneurship competencies. This is due to several circumstances such as; (1) The program was carried out simultaneously during the first semester of 2016/2017 academic calendar, student schedule was very tight (2) respondents came from multidiscipline academic background and faculties, so it difficult for them to meet in day time and (3) their sewing skills are very limited. These circumstances have manifested as constraints for the respondents to find a suitable time to meet with their group members and mentors as they needed guidance and help. At the same time, they could not give full commitment as they have other commitments that they need to fulfill. These findings supported Chang and Rieple (2013) who stressed that entrepreneurship education programs need to be schedule in a more structured and timely manner. So it can be concluded that the time consideration plays an important role to ensure the implementation of a program can be achieved. At the same time, students can benefit from all the activities planned and apply this knowledge in the future.

Even though this research showed no significant relationship between entrepreneurship education with entrepreneurship intentions and entrepreneurship competencies but this study has provided tremendous benefits to the respondents. Having skills or knowledge on entrepreneurship alone is not sufficient to drive the students to venture into entrepreneurship. Students need support in the form of practical activities or hands-on to enable them to acquire knowledge from their entrepreneurship environment. This coincided with Chang and Rieple (2013) who stated that the development of entrepreneurial skills can be improved by providing a learning environment in which students interact with real business people in live projects (Cedefop, 2006; Syed Zamberi, 2012, Nabi, et al., 2018). The main benefits gained by the respondents from this program where they had the opportunity to work and receive extensive exposure, support and direct guidance from the mentors. Mentoring system indirectly helped to increase their interest to venture into fashion entrepreneurship. The more these future entrepreneurs know about the availability of these environmental driving forces, the higher the chances of them developing entrepreneurship intentions. (Khuong \& An, 2016). Other than that, respondents also gained countless benefits from the financial support provided by the organizer. Fund grants could provide the opportunity for the respondents to perform various activities that require a financial to complete it.

In the context of Malaysia, very limited studies have been conducted to analyze the impact of entrepreneurship education on entrepreneurship outcomes. Hence this study has been conducted to see the impact of learning by doing activities through fashion entrepreneurship project known as Siswa@Fesyen on students' entrepreneurship outcomes. Results of this study validated the Model of Entrepreneurship Learning and Entrepreneurship Intentions Model. The results of this study also demonstrated that prior entrepreneurship experiences were considered more significant and more positive compared to the other main factors on modelling students' future profession as well as developing entrepreneurship as the key breadwinner of the economy.

\subsection{Conclusion}

Siswa@ Fesyen is a development program that focuses on nurturing graduates to become successful entrepreneurs. This program combined several important components in providing knowledge and training to students as preparation and platform to enable students to venture into business and entrepreneurship. This program supports the implementation of Entrepreneurship Development Policy Higher Education Institutions (HEIs) 2016 to 2020, which aims to create more job creators rather than job seekers among university graduates. This program can also be a precursor to the university to multiply such programs in order to increase the interest and the entrepreneurship among university students.

\subsection{Limitations of the Study and Future Researches}

First of all, the most important and practical implication that can be drawn from this research is the role of entrepreneurial education. In terms of economics and social, concentrate on the development of internship programs which provide more opportunities for youngsters to practice in real working conditions and professional environment.

Due to time constraints, the data are limited to a small size of samples at only one university in Malaysia. The findings of this study did not permit generalization and this study should be extended to other programs offered in tertiary education in Malaysia in order to obtain more accurate results. It is suggested that the program developed in this study should apply at other universities as well. The variables that we discussed in this study are limited and did not cover the whole factors that may have an influence on entrepreneurial intentions and competencies. Thus, we recommend that future researchers to look into other variables that have not been tested in this study.

\section{Acknowledgement}

The authors acknowledge the support of Entrepreneurship Division and Public-Private Research Network (PPRN), Ministry of Higher Education Malaysia through Centre of Entrepreneurial Development and Graduate Marketability (CEM) University of Putra Malaysia for the given research grant. We would also like to thank our respondents who contributed with their time and insight. Special thanks to the mentors, fashion experts and staffs for helping us execute the research successfully. 


\section{References}

Armanurah, M., Abdul Razak, A., \& Syahrina, A. (2005). Kepentingan pendidikan keusahawanan kepada organisasi dan negara. National Conference on Skills and Competencies in Education, (pp. 101-106).

Bygrave, W. D. (1989). The entrepreneurship paradigm: a philosophical look at research methodologies. Entrepreneurship Theory and Practice, 14(1), 7-26.

Cedefop (2009). European guidelines for validating non-formal and informal learning. Luxembourg: Publications Office. Available from Internet http://www.cedefop. europa.eu/etv/Upload/Information_resources/Bookshop/

$553 / 4054$ en.pdf

Chang, J., \& Rieple, A. (2013). Assessing students' entrepreneurial skills development in live projects. Journal of SmallBusiness and Enterperise Development, 30(1), 225-241.

Doğan*, E. (2015). The effect of entrepreneurship education on entrepreneurial intentions of university students in Turkey. Ekonometri ve Istatistik Sayi, 23, 79-93.

Economic Planning Unit. (2015). Eleventh Malaysia Plan 2016-2020 Anchoring growth on people. Kuala Lumpur: Percetakan Nasional Malaysia Berhad.

Hussain, A., \& Norashidah. (2015). Impact of entrepreneurial education on entrepreneurial intentions of Pakistani students. Journal of Entrepreneurship and Business Innovation, 2(1), 2332-8851.

Izedonmi, Prince Famous, \& Chinonye, O. (2010). The effect of entrepreneurship education on students entrepreneurial intentions. Global Journal of Management and Business Research, 10(6), 49-60.

Khuong, M. N., \& An, N. H. (2016). The factors affecting entrepreneurship intention of the students of Vietnam National University - A mediation analysis of perception toward entrepreneurship. Journal of Economics, Business and Management, 4(2), 104-111.

Key Statistic of Labour Force in Malaysia (June, 2018). Retrieved from https://www.dosm.gov.my.

Kourilsky , M. L., \& Walstad, W. B. (1998). Entrepreneurship and female youth: Knowledge, attitudes, gender differences, and educational practices. Journal of Business Venturing, 13(1), 77-88.

Krueger, N. F., \& Carsrud, A. L. (1993). Entrepreneurial intentions: applying the Theory of Planned Behavior. Entrepreneurship \& Regional Development, 5(4), 315-330.

Lackeus, M. (2015). Entrepreneurship in education what, why, when, how. European Commission.

Linan, F., Rodriguez-Cohard, J. C., \& Rueda-Cantuche, J. M. (2011). Factors affecting entrepreneurial intention levels:a role for education. International Entrepreneurship and Management Journal, 7(2), 195-218.

Ministry of Education Malaysia. (2013). Malaysian Education Blueprint 2013-2025 pre-school to post-secondary education. Putrajaya: Ministry of Education Malaysia.

Matlay, H. (2008). The impact of entrepreneurship education on entrepreneurial outcomes. Journal of Small Business and Enterprise Development, 15(2), 382-396.

McClelland, D. C. (1985). Human motivation. Glenview, IL: Scott, Foresman.

Mohd Khairuddin, H., \& Syed Azizi, W. (2002). Small and medium-sized enterprises in Malaysia: development issues. Kuala Lumpur: Prentice Hall Pearson.

Nabi, G., Walmsley, A., Linan, F., Akhtar, I., \& Neame, C. (2018). Does entrepreneurship education in the first year of higher education develop entrepreneurial intentions? The role of learning and inspiration. Studies in Higher Education, $43(3), 452-467$.

Noorkartina, M., Hock-Eam, L., Norhafezah, Y., \& Jan-Jan, S. (2015). Estimating the effect of entrepreneur education on graduates' intention to be entrepreneurs. Education and Training, 57(8/9), 874-890.

Norashidah Hashim, Norasmah Othman, \& Noraishah Buang. (2009). Konsep kesediaan keusahawanan berdasarkan kajian kes usahawan Industri Kecil dan Sederhana (IKS) di Malaysia. Jurnal Pendidikan Malaysia, 34(1), $187-203$.

Norasmah Othman, Norashidah Hashim, \& Hariyaty Ab. Wahab. (2012). Readiness towards entrepreneurship education students and Malaysian universities. Education + Training, 54(8/9), 697-708. 
Peterman, N. E., \& Kennedy, J. (2003). Enterprise education: Influencing students' perceptions of entrepreneurship. Entrepreneurship theory and practice, 28(2), 129-144.

PricewaterhouseCoopers (PwC) (2015). 2015-2016 Outlook for the retail and consumer products sector in Asia. Retrieved from https:/www.pwc.com/id/en/publications/ assets/cips/2015-16-outlook-for-the-retail-and-consumerproducts-sector-in-asia.pdf

Rasmussen, E. A., \& Sørheim, R. (2006). Action-based entrepreneurship education. Journal of Technovation, 26, 185194.

Syed Zamberi, A. (2012). The need for inclusion of entrepreneurship education in Malaysia lower and higher learning institutions. Education and Training, 55(2), 191-203.

Zhang, Y., Duysters , G., \& Cloodt, M. (2013). The role of entrepreneurship education as a predictor of university students' entrepreneurial intention. International Entrepreneurship and Management Journal. 